\title{
Front Matter: Volume 10779
}

, "Front Matter: Volume 10779," Proc. SPIE 10779, Lidar Remote Sensing for Environmental Monitoring XVI, 1077901 (3 December 2018); doi: $10.1117 / 12.2520654$ SPIE. Event: SPIE Asia-Pacific Remote Sensing, 2018, Honolulu, Hawaii, United 


\title{
Lidar Remote Sensing for Environmental Monitoring XVI
}

\author{
Upendra N. Singh \\ Nobuo Sugimoto \\ Editors
}

\section{4-25 September 2018 \\ Honolulu, Hawaii, United States}

Sponsored by

SPIE

Cosponsored by

NASA-National Aeronautics and Space Administration (United States)

RADI-Institute of Remote Sensing and Digital Earth, Chinese Academy of Sciences (China)

State Key Laboratory of Remote Sensing Science, Chinese Academy of Sciences (China)

Ministry of Earth Sciences (India)

\section{Cooperating Organizations}

University of Hawai'i at Mānoa (United States)

JAXA-Japan Aerospace Exploration Agency (Japan)

NICT-National Institute of Information and Communications Technology (Japan)

ISRO_Indian Space Research Organization (India)

ESSO-Earth System Science Organization (India)

Published by

SPIE 
The papers in this volume were part of the technical conference cited on the cover and title page. Papers were selected and subject to review by the editors and conference program committee. Some conference presentations may not be available for publication. Additional papers and presentation recordings may be available online in the SPIE Digital Library at SPIEDigitalLibrary.org.

The papers reflect the work and thoughts of the authors and are published herein as submitted. The publisher is not responsible for the validity of the information or for any outcomes resulting from reliance thereon.

Please use the following format to cite material from these proceedings:

Author(s), "Title of Paper," in Lidar Remote Sensing for Environmental Monitoring XVI, edited by Upendra N. Singh, Nobuo Sugimoto, Proceedings of SPIE Vol. 10779 (SPIE, Bellingham, WA, 2018) Seven-digit Article CID Number.

ISSN: 0277-786X

ISSN: 1996-756X (electronic)

ISBN: 9781510621336

ISBN: 9781510621343 (electronic)

Published by

SPIE

P.O. Box 10, Bellingham, Washington 98227-0010 USA

Telephone +1 3606763290 (Pacific Time) · Fax +1 3606471445

SPIE.org

Copyright (C) 2018, Society of Photo-Optical Instrumentation Engineers.

Copying of material in this book for internal or personal use, or for the internal or personal use of specific clients, beyond the fair use provisions granted by the U.S. Copyright Law is authorized by SPIE subject to payment of copying fees. The Transactional Reporting Service base fee for this volume is $\$ 18.00$ per article (or portion thereof), which should be paid directly to the Copyright Clearance Center (CCC), 222 Rosewood Drive, Danvers, MA 01923. Payment may also be made electronically through CCC Online at copyright.com. Other copying for republication, resale, advertising or promotion, or any form of systematic or multiple reproduction of any material in this book is prohibited except with permission in writing from the publisher. The CCC fee code is 0277$786 \mathrm{X} / 18 / \$ 18.00$.

Printed in the United States of America.

Publication of record for individual papers is online in the SPIE Digital Library.

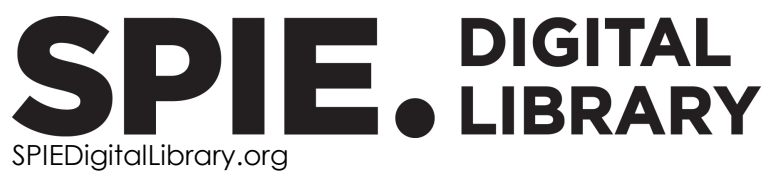

Paper Numbering: Proceedings of SPIE follow an e-First publication model. A unique citation identifier (CID) number is assigned to each article at the time of publication. Utilization of CIDs allows articles to be fully citable as soon as they are published online, and connects the same identifier to all online and print versions of the publication. SPIE uses a seven-digit CID article numbering system structured as follows:

- The first five digits correspond to the SPIE volume number.

- The last two digits indicate publication order within the volume using a Base 36 numbering system employing both numerals and letters. These two-number sets start with $00,01,02,03,04$, 05, 06, 07, 08, 09, 0A, OB ... 0Z, followed by 10-1Z, 20-2Z, etc. The CID Number appears on each page of the manuscript. 


\title{
Contents
}

\author{
$\checkmark \quad$ Authors \\ vii Symposium Committees \\ ix Conference Committee
}

SESSION 1 SPACEBORNE LIDAR I

$1077902 \quad$ Airborne direct-detection 2- $0 \mathrm{~m}$ triple-pulse IPDA lidar integration for simultaneous and independent atmospheric water vapor and carbon dioxide active remote sensing (Invited Paper) [10779-1]

1077903 Development of Tm,Ho: YLF laser for future space-based doppler wind lidar [10779-2]

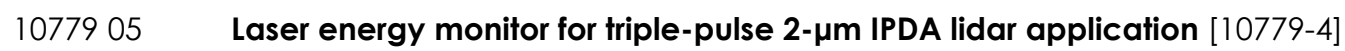

1077906 Lidar measurements of $\mathrm{CO}_{2}$ column concentrations in the Arctic region of North America from the ASCENDS 2017 airborne campaign [10779-5]

SESSION 2 SPACEBORNE LIDAR II

$1077908 \quad$ Lifetime testing of a 355-nm, space-qualifiable laser [10779-7]

SESSION $3 \quad$ ATMOSPHERIC MEASUREMENTS

10779 OC Lidar application to monitoring emissions and transport of particulate pollution in urban environments with high temporal and spatial resolution (Invited Paper) [10779-11]

10779 OD Lidar validation measurements at the NOAA Mauna Loa Observatory NDACC Station [10779-13]

$10779 \mathrm{OF}$ Simultaneous observation of temporal and spatial distribution of atmospheric aerosol by means of slant-path and plan position indicator lidars [10779-15]

10779 OG Active standoff mixing-ratio measurements of $\mathrm{N}_{2} \mathrm{O}$ from topographic targets using an open-path quantum cascade laser system [10779-16] 
$10779 \mathrm{OH} \quad$ Multiwavelength scanning standoff time-resolved Raman system for planetary exploration and environmental monitoring (Invited Paper) [10779-17]

10779 Ol Raman lidar in operational meteorology [10779-18]

10779 OJ Standoff Biofinder: powerful search for life instrument for planetary exploration [10779-19]

10779 OK Stand-off detection of amino acids and nucleic bases using a compact instrument as a tool for search for life [10779-20]

10779 OL Modified spatial heterodyne Raman spectrometer for remote-sensing analysis of organics [10779-21]

\section{SESSION 5 FLUORESCENCE AND OTHER LIDAR METHODS}

10779 OM A fluorescence lidar for seamlessly connecting individual observations of the global environmental systems (Invited Paper) [10779-22]

1077900 Analysis of predictor variables for mosquito species identification from dual-wavelength polarization-sensitive lidar measurements [10779-24]

10779 OP Extraction of collapsed buildings due to the 2016 Kumamoto, Japan, earthquake using two-temporal Lidar data [10779-25]

$107790 Q \quad$ Unmanned aircraft system-based lidar survey of structures above and below the water surface: Hilo Deep Draft Harbor Breakwater, Hawaii [10779-26]

\section{POSTER SESSION}

10779 OU From prototype system to practical application of hyperspectral LiDAR: Investigation of the intraday 3D variations of tree biophysics and biochemistry [10779-30]

10779 OZ Using a CCD camera lidar system for detection of Asian dust [10779-36]

1077910 Development of conductively cooled Tm,Ho:YLF MOPA for lidar applications [10779-37]

1077911 Improvement of CSF based on a wide range of urban complex scenes [10779-38]

$1077912 \quad$ Aerosol monitoring with a lidar observation network in the southern South America [10779-39] 


\section{Authors}

Numbers in the index correspond to the last two digits of the seven-digit citation identifier (CID) article numbering system used in Proceedings of SPIE. The first five digits reflect the volume number. Base 36 numbering is employed for the last two digits and indicates the order of articles within the volume. Numbers start with 00, 01, 02, 03, 04, 05, 06, 07, 08, 09, OA, OB...0Z, followed by 10-1Z, 20-2Z, etc.

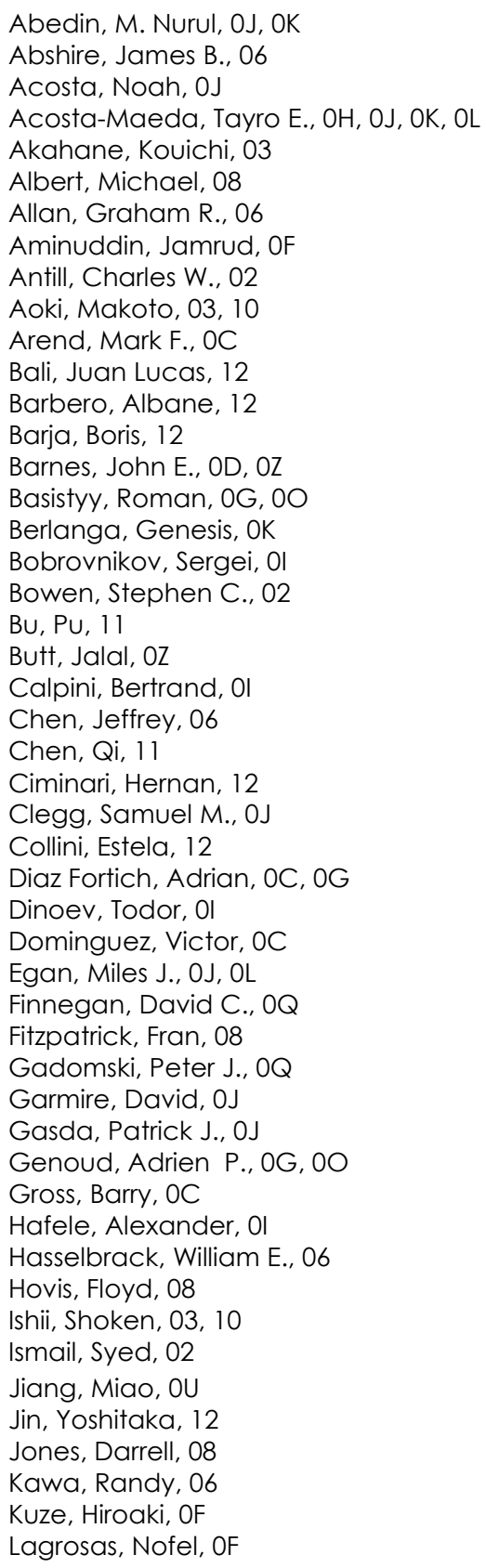

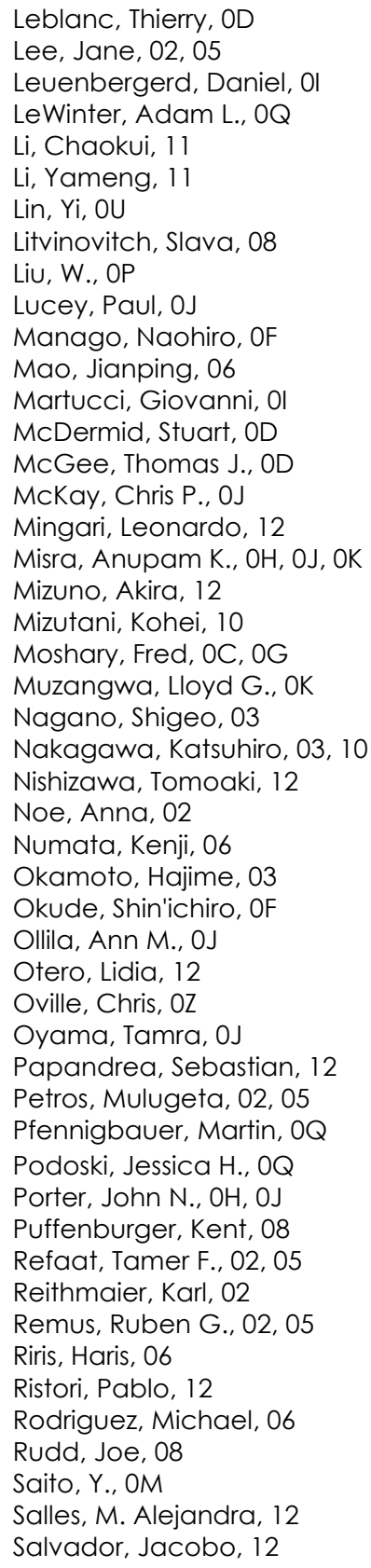


Sandford, Macey, 0J

Sato, Atsushi, 03, 10

Sato, Kaori, 03

Schum, Tom, 08

Schwarz, Roland, $0 Q$

Serikov, llya, ol

Sharma, Nimmi C. P., OZ

Sharma, Shiv K., OH, OJ, OK, OL

Shimizu, Atsushi, 12

Shiraishi, K., OM

Simeonov, B. Valentin, 0 I

Singh, Upendra N., 02, 05

Stephen, Mark, 06

Sugimoto, Nobuo, 12

Sullivan, John T., OD

Sumnicht, Grant K., OD

Taylor, Bryant D., 02

Thomas, Benjamin P., 0G, 00

Tomida, T., OM

Truong, My-Linh, OQ

Twigg, Laurence W., OD

Vladutescu, Daniella Viviana, OC

Welters, Angela M., 02

Wiens, Roger C., OJ

Williams, Gregory M., 00

Wong, Teh-Hwa, 02, 05

Wu, Yonghua, $0 \mathrm{C}$

Yamazaki, F., OP

Zhou, Jie, OJ 


\title{
Symposium Committees
}

\author{
Symposium Chair
}

Upendra N. Singh, NASA Langley Research Center (United States)

Symposium Co-chairs

Toshiyoshi Kimura, Japan Aerospace Exploration Agency (Japan)

K. J. Ramesh, Ministry of Earth Sciences (India)

Jiancheng Shi, Institute of Remote Sensing and Digital Earth (China)

Honorary Symposium Chairs

Huadong Guo, Institute of Remote Sensing and Digital Earth (China)

Stephen Jurczyk, National Aeronautics and Space Administration (United States)

A. S. Kiran Kumar, Indian Space Research Organisation (India)

Jean-Yves Le Gall, Centre National d'Études Spatiales (France)

Robert M. Lightfoot, Jr., National Aeronautics and Space

Administration (United States)

Madhavan N. Rajeevan, Ministry of Earth Sciences (India)

Alain Ratier, EUMETSAT (Germany)

Hiroshi Yamakawa, Japan Aerospace Exploration Agency (Japan)

Symposium International Organizing Committee

Michael H. Freilich, Chair, National Aeronautics and Space Administration (United States)

Jack A. Kaye, National Aeronautics and Space Administration (United States)

Barry L. Lefer, National Aeronautics and Space Administration (United States)

Clayton P. Turner, NASA Langley Research Center (United States)

Pamela Millar, NASA Goddard Space Flight Center (United States)

David F. Young, NASA Langley Research Center (United States)

Tapsan Misra, Indian Space Research Organisation (India)

Kazuo Tachi, Japan Aerospace Exploration Agency (Japan) 
Katsuhiro Nakagawa, National Institute of Information and

Communications Technology (Japan)

Haruhisa Shimoda, Tokai University (Japan)

Kohei Mizutani, National Institute of Information and

Communications Technology (Japan)

Wonkook Kim, Korea Institute of Ocean Science and Technology (Republic of Korea)

YoungJe Park, Korea Institute of Ocean Science and Technology (Republic of Korea)

Jhoon Kim, Yonsei University (Republic of Korea)

Xianqiang He, Second Institute of Oceanography, State Oceanic Administration (China)

Shunling Liang, Beijing Normal University (China) 


\title{
Conference Committee
}

\author{
Conference Chairs
}

Upendra N. Singh, NASA Langley Research Center (United States)

Nobuo Sugimoto, National Institute for Environmental Studies (Japan)

\section{Conference Program Committee}

Makoto Abo, Tokyo Metropolitan University (Japan)

Weibiao Chen, Shanghai Institute of Optics and Fine Mechanics (China)

Takashi Fujii, Central Research Institute of Electric Power Industry (Japan)

Parminder Ghuman, NASA Goddard Space Flight Center (United States)

Floyd Hovis, Fibertek, Inc. (United States)

Shoken Ishii, National Institute of Information and Communications Technology (Japan)

Achuthan Jayaraman, National Atmospheric Research Laboratory (India)

Philippe L. Keckhut, LATMOS (France)

Sang-Woo Kim, Seoul National University (Korea, Republic of)

Dong Liu, Anhui Institute of Optics and Fine Mechanics (China)

Thomas J. McGee, NASA Goddard Space Flight Center (United States)

Anupam K. Misra, University of Hawaili (United States)

Fred Moshary, The City College of New York (United States)

Mulugeta Petros, NASA Langley Research Center (United States)

Tamer F. Refaat, NASA Langley Research Center (United States)

Tetsu Sakai, Meteorological Research Institute (Japan)

Daisuke Sakaizawa, Japan Aerospace Exploration Agency (Japan)

Shiv K. Sharma, Hawai'i Institute of Geophysics and Planetology (United States)

Takashi Shibata, Nagoya University (Japan)

Tatsuo Shiina, Chiba University (Japan)

Georgios Tzermes, European Space Agency (Netherlands)

Bhavani Kumar Yellapragada, National Atmospheric Research Laboratory (India)

Fan Yi, Wuhan University (China) 


\section{Session Chairs}

1 Spaceborne Lidar I

Upendra N. Singh, NASA Langley Research Center (United States)

Shoken Ishii, National Institute of Information and Communications Technology (Japan)

2 Spaceborne Lidar II

Hajime Okamoto, Kyushu University (Japan)

Mulugeta Petros, NASA Langley Research Center (United States)

3 Atmospheric Measurements

Nobuo Sugimoto, National Institute for Environmental Studies (Japan)

Tamer F. Refaat, NASA Langley Research Center (United States)

4 Raman and Standoff Detection

Fred Moshary, The City College of New York (United States)

Floyd Hovis, Fibertek, Inc. (United States)

$5 \quad$ Fluorescence and Other Lidar Methods

Shiv Kumar Sharma, Hawai 'i Institute of Geophysics and Planetology (United States)

Thomas J. McGee, NASA Goddard Space Flight Center (United States) 